\title{
O baião e outras bossas, são coisas nossas
}

(MAIA ALVES, Elder P. A sociologia de um gênero: o baião. Maceió: Edufal, 2012. 386 p.)

Diego R. Araoz Alves*

$\mathrm{O}$ leitor de A sociologia de um gênero: o baião, escrito por Elder Maia Alves, é convidado a enveredar em uma bela narrativa sobre as culturas ditas populares e sertanejas. Fundado no espírito crítico e no gosto pelo tema, a sociologia do baião celebra também o centenário de Luiz Gonzaga, o seu principal "artífice". A obra é um reflexo da bagagem que o pesquisador vem acumulando sobre a economia simbólica de culturas geográfica e discursivamente referidas ao "sertão nordestino". Sua intenção é decifrar um irresistível enigma da nossa música popular, colocando em perspectiva uma clássica dicotomia do nosso pensamento social. Afinal, "por que um gênero musical de matriz rural só se definiu e se sistematizou no espaço urbano?" (p. 18). Respostas são encontradas aqui e ali, sob uma análise que apenas a aliança entre o rigor na descrição historiográfica e a sensibilidade enriquecida no âmbito da sociologia da cultura poderia favorecer. De estilo persuasivo e esclarecedor, o livro coloca em tela as consequências de um determinado tipo de modernização da cultura ocorrida no Brasil do século passado, que vale comentar. Pois, a sociologia do baião é feita de quê?

Elder Maia Alves propõe que a arte de retratar o baião seja a arte de desenhar a abrangência e articulação dos processos subjacentes à sistematização rítmica e melódica do gênero, simultânea a sua especialização em música popular brasileira. Processos que são de muitas naturezas e dinamizados a propósito de uma multiplicidade de questões; num jogo que pode provocar no leitor a sensação de que as categorias baião e sertão relacionam-se de forma metonímica. Mas não. De saída, a análise descreve o modo como vários sertões concorrem solidariamente na rica diversidade musical do início do século XX; época em que a cidade do Rio de Janeiro, secundada por São Paulo, parece ter se especializado em um lugar onde o sertão é mais sertão. Alves aponta para o fato de que a condição de principal destino do fluxo migratório do país e a nascente indústria cultural naquelas metrópoles forjou as bases sociais e psicológicas da moderna cultura sertaneja. Assim importa codificar o sertão não apenas como alteridade reinventada na experiência urbana, mas também como a espécie de bem memorialista que se difunde no imaginário sobre muitos brasis. Os dados cole-

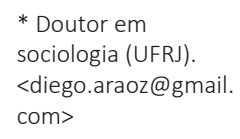

* Doutor em sociologia (UFRJ). <diego.araoz@gmail. com> 
tados pelo autor falam por si. Demonstram a existência de quase que um fetichismo regionalista, cujas imagens teriam sido veiculadas através das viagens de músicos país afora, a exemplo das excursões do conjunto Oito Batutas ou do Turunas da Mauriceia; de equipamentos culturais e espaços urbanos diversos, como cinemas, teatros e cafés; de tecnologias de reprodução fonográfica, como o rádio e o disco; ou, alegoricamente, em ritos da magnitude do carnaval. E muito mais. Costurados o denso tecido social e a intensa circulação de culturas musicais, que dão amplitude aos significados das representações sertanejas nas metrópoles da primeira metade do século, temos as condições para desemaranhar a genética do advento do baião.

É uma interessante seleção de narrativas de cronistas, folcloristas, modernistas e demais pesquisadores que autoriza uma leitura dos gêneros sertanejos tal qual a história social de projetos possíveis. Projetos que, ao fim e ao cabo, ensaiam o destino do baião. A narrativa sociológica do baião baralha os relatos sobre inúmeras formas musicais, em análise diacrônica que não incorre nem em anacronismos estreitos nem em um ingênuo evolucionismo. Por exemplo, as trajetórias dos inventores do baião, Luiz Gonzaga e Humberto Teixeira, são lidas como modelos tardios das de "artífices" como Catulo da Paixão Cearense ou João Pernambuco. No sentido de que suas biografias oferecem bons elementos para pensar usos de modo nenhum inéditos que os indivíduos fazem da vitalidade de suas tradições, altamente interessantes para contextos com práticas sociais em vias de modernização. Eis o coração do enigma, que consiste em distinguir os tipos de mediação de uma ou outra tradição. O terceiro dos cinco capítulos do livro reserva o núcleo da tese. Nele, a história social do baião como um projeto, é reconstituída a partir dos acidentes, das tentativas que precedem o gênero: balancês, seridós, xamegos, xotes, xeréns e não apenas. Sim, nomear é dominar! O baião é visto como resultado da mescla de experimentos, mais algum senso de oportunidade por parte dos "artífices", frente aos desenvolvimentos tecnológicos e da industrialização do simbólico no campo da música. Em resumo, a novidade acontece na medida em que se complexificam, profissionalizam e especializam as relações entre "arte, técnica, memória e mercado" (p. 132).

As fábulas refinam a imaginação sociológica. A do encontro do jovem Gonzaga com estudantes cearenses no Rio de Janeiro é decisiva à narrativa. O inesperado pedido do grupo para o sanfoneiro, que tocasse "ritmos do Norte", é contado como a pedra de toque para o projeto de sistematização dos gêneros sertanejos que o compositor veio a realizar entre as décadas de 1930 e 1940. O estimulo dado pelos jovens universitários do Norte teria semeado, naquilo tudo que a obra de Luiz Gonzaga inova, "a face mais viva do regionalismo e do nacionalismo musical que vinha se urdindo desde as primeiras décadas do século XX" (p. 213). Elder Maia Alves descreve, então, as miudezas das trajetórias sociais e artísticas concatenando-as à economia da cultura imaterial sertaneja. A memória - fonte nostálgica que sintetiza as referências 
regionais, rítmicas, melódicas, dançantes, poéticas, lúdicas, afetivas, paisagísticas, libidinosas, linguísticas, mitológicas - é incrementada com o âmbito da produção e do consumo da música. A imbricada relação entre mercado e memória configura o principal índice na interpretação da formação da música popular brasileira pela sociologia do baião. A um só tempo, este índice forja um sistema que, no limite, hierarquiza para cima a dimensão política e a mercadológica em relação às coisas da memória no processo de especialização do baião, revelando o papel da previsibilidade, do cálculo e das estratégias que, sociologicamente, possibilitam este ou aquele fato artístico. Na leitura proposta por Alves, essa característica não seria um privilégio do baião. Ela pode ser observada de maneira exemplar ao longo da formação do samba, cuja história social, aliás, oferta um termo de comparação importantíssimo para o argumento.

Como categoria sociológica, baião é igualmente feito de crítica. Principalmente da crítica que rejeitou sua classificação como fato folclórico, diferenciando seu contexto de invenção mais ainda do "coco de embolada" e "moda de viola caipira". Alves nos mostra que na pena de jornalistas, e no mundo das gravadoras, as particularidades musicológicas dos dois últimos gêneros se anulam sob o rótulo de "música sertaneja". A partir da indistinção elaborada pela incipiente indústria cultural pré-baião, que folcloriza fontes arcaicas da música rural urbanizada, o autor enfrenta uma difícil classificação dos gêneros, a dinamicidade de suas reinvenções, a influência das primeiras tecnologias e do imaturo mercado musical, a complexidade de um mundo artístico em formação, os vários planos que envolvem a relação entre o rural e o urbano. Entretanto, exceções à critica que homogeneíza os gêneros sertanejos são identificadas em empresas como a de Mário de Andrade que, nos diz o autor, descreve a evolução da música popular defendendo uma fusão, e não as incorporações e as profusões, entre os gêneros sertanejos (p. 73 e 90), ou a de um caipirólogo como Cornélio Pires, que gravou pioneiramente em disco a diversidade de gêneros musicais rurais paulistas ( $p$. 83). Contudo, os espaços ainda mais significativos de legitimação artística das músicas rurais viriam do gosto de determinados segmentos intelectuais da dita belle époque no Rio de Janeiro (p. 135-165). No contexto de advento do baião, as linhagens jornalísticas da música popular se atualizariam com a emergência dos "folcloristas do rádio", em destaque a figura de Almirante, comunicador contagiado pelo demônio do colecionismo e defensor das coisas nacionais (p. 170-178). Já os críticos profissionalmente especializados em música popular representariam outra vertente, da qual a Revista da Música Popular seria o seu arauto por excelência (p. 351-366).

Sem dúvida, Mário de Andrade, símbolo de nosso Modernismo, é o interlocutor principal da sociologia do baião. As citações à sua obra atravessam toda narrativa do livro, que reserva ainda um capítulo especialmente dedicado ao estudo das estratégias estéticas e políticas do movimento modernista na construção da identidade brasileira. 
É como se a sociologia do baião elaborasse, paralelamente à sua história social, a resenha do movimento modernista através do perfil marioandradeano e de seu pensamento musical nacionalista. Assim como diversos outros intelectuais com apreço pelas coisas do povo, Mário performatiza uma espécie de "meio giro sobre os próprios pés". Expressão que assume uma conotação quase que proverbial na análise sobre os mundos da crítica e da pesquisa da música popular ao longo do século XX. Alves propõe um contraponto entre o Modernismo e as "teorias musicais e discussões estéticas mais esotéricas", a exemplo das de "folcloristas do rádio", em relação à industrialização do simbólico. Sugere que, a despeito da quase invisibilidade mútua, nenhuma dessas vertentes passaram incólumes à expansão do mercado musical e publicitário (p. 196). Pois se, de um lado, os "folcloristas do rádio" agenciaram engajadamente a industrialização do simbólico, do outro, este mesmo processo contribui para explicar até mesmo certas inflexões no pensamento do poeta modernista: a rejeição do caráter nacional da música popular urbana nos anos 1920 ou a sua valorização nos anos 1940 (p. 208-210).

O exame da industrialização do simbólico, um processo macrossociológico que normatiza as ações de agentes tradicionalizadores, acaba tocando num ponto por demais relevante. Tanto "artífices" da música popular como as construções intelectuais "mais esotéricas" compartilham de um horizonte próximo ao ideário modernista: a valorização da linguagem oral e despojada do cotidiano como fonte para abrasileiramentos, as justaposições narrativas entre passado e presente, a bricolagem como forma de descrição de temas folclóricos e outros mais. Esses aspectos, de natureza fragmentada e tão propicia no contexto urbano, encontram-se igualmente subjacentes seja na ativação da memória da infância sertaneja de Luiz Gonzaga, de Humberto Teixeira e de Zé Dantas, na sistematização do baião, seja na interface entre memória e mercado que o microfone de Almirante habilmente construiu através do rádio. Ou, de modo mais peculiar ainda do que nas formas literárias e sonoras, na produção cinematográfica do sertão (p. 275-307).

A categoria sociológica baião é acima de tudo uma tipologia. Uma tipologia do poder de nomeação exercido pelos "artífices" na composição tornada gênero musical; está a serviço da descrição dos códigos sociais que informaram a possibilidade daquela classificação; e construída a propósito de uma modernização cultural através da qual o "sucesso comercial e artístico do baião condensou e vinculou o sertão ao nordeste" (p. 369). Nesse difícil e tão necessário exercício de imaginação sociológica, o autor lança mão de uma dicção eliasiana aplicada com medida para descrever o advento do baião e sua contemporaneidade, mesmo no âmbito das políticas públicas culturais. Além desse artifício, vale destacar o uso do extenso repertório de conceitos compostos com os quais busca traduzir várias ambiguidades de um regionalismo que se nacionaliza e de um nacionalismo que se regionaliza. 
Lá se vão duas décadas desde que Hermano Vianna prefaciou O encontro entre Bandeira e Sinhô. Na ocasião, ele nos disse que pouco importava qual seria o ponto de chegada, seja o do olhar antropológico de seu O mistério do samba, seja o da descrição de viés literário daquele livro de André Gardel, diante das "artimanhas do nosso espírito do tempo". O testemunho expressava o sentimento sobre um acontecimento especial, e nada mágico: a sincronicidade que as duas abordagens encenaram sem levantar suspeita. Quando aqueles livros foram publicados, o tema das mediações culturais de coisas tão brasileiras já havia algum tempo se consolidado como assunto relevante na agenda das nossas ciências sociais. Desde pelo menos os anos 1980, o exercício de desmistificação de coisas tão nossas descentralizou o papel de questões ligadas à identidade nacional, por exemplo, em detrimento de um enquadramento crítico e sem apriorismo de mediações e experiências do dia a dia, principalmente no mundo urbano. A vida concreta, digamos.

O assunto irrompe fortemente nesta sociologia do baião, cujo mito de origem foi fartamente documentado. De modo explícito, o livro sugere que desconstruir mitos é um meio de livrar a apreensão da dimensão processual em seus múltiplos planos sociais. Para tanto, considera que a vida simbólica das coisas, aquela inescapável à expansiva industrialização, deve ser observada naquilo que imprime quase que de maneira corpórea no espírito humano. Assim, na busca de processos de inculcação, a análise aposta na confrontação das pistas oferecidas pelo mito com o direito de existência dos "artífices" assegurado pela escrita biográfica. Entretanto, se os dados biográficos moldam-se a uma prosopografia configuracional, que desafios poderiam ser esperados se levada às últimas consequências a mediação elaborada pelos biógrafos? Este gênero literário, por demais caro à sociologia do baião, faz da sua matéria-prima, a confissão, uma via de mão dupla. Talvez por isso mesmo que, de modo implícito, o trabalho de desmistificação do livro não reivindique um completo rompimento com determinada literatura diletante e nem a marginalize devido uma suposta fragilidade metodológica. Antes, sustenta uma relação dialógica, produtiva e significativamente tensa, com aquelas autoridades narrativas que concorrem para dizer de maneira simples o que os gêneros da música popular brasileira realmente são. Ganha com isso o leitor, que assiste e participa de uma espirituosa dança, envolvendo a humilde e saborosa contribuição de biografias e de crônicas na condição de gêneros que mediam, com grande poder de interpelação, o ensaio científico.

O convite à leitura está feito, mais uma vez. 


\section{Referências}

GARDEL, André. O encontro entre Bandeira e Sinhô. Rio de Janeiro: Secretaria Municipal de Cultura, 1996.

VIANNA, Hermano. O mistério do samba. Rio de Janeiro: Zahar; Editora UFRJ, 1995. 